\title{
Structural and functional changes in ovaries from adult mice treated with diethylstilboestrol in the neonatal period
}

\author{
A. Tenenbaum and J.-G. Forsberg \\ Department of Anatomy, University of Lund, S-223 62 Lund, Sweden
}

\begin{abstract}
Summary. Ovaries from 8-week-old female NMRI mice in different stages of the oestrous cycle, or from females neonatally treated with the synthetic oestrogen diethylstilboestrol (DES; $5-10^{-6} \mu \mathrm{g}$ daily for 5 days), were studied histologically and for the ability to synthesize steroids from $\left[{ }^{3} \mathrm{H}\right]$ pregnenolone in vitro. Daily doses of $10^{-4} \mu \mathrm{g}$ DES or higher resulted in absence of corpora lutea. In ovaries lacking corpora lutea, the interstitial tissue dominated and the cells in this compartment were large with a clear cytoplasm.

The steroids synthesized in ovarian homogenates were separated with thin-layer chromatography. The homogeneity of the steroids was checked in recrystallization experiments. Daily doses of $5-10^{-4} \mu \mathrm{g}$ DES in the neonatal period resulted in pronounced deviations in the pattern of ovarian steroids synthesized as compared with control ovaries. In DES-exposed ovaries, the synthesis of androstenedione and, above all, progesterone was high while the synthesis of 17 -hydroxyprogesterone and testosterone was reduced compared with controls. These results could argue for a difference in activities of $17 \alpha$-hydroxylase and $17 \beta$-ol-dehydrogenase in ovaries from DES-treated females compared with controls. After transplantation of DES-exposed ovaries to ovariectomized control females, the steroid pattern changed to that typical for control ovaries. Control ovaries transplanted to DES-treated females had a steroid pattern similar to that of DES-exposed ovaries.
\end{abstract}

\section{Introduction}

In 1962, Takasugi, Bern \& DeOme described a persistent vaginal cornification in adult mice treated with oestrogen in the neonatal period. Later, a dose-dependent vaginal response was reported; high doses of oestradiol resulted in ovary-independent vaginal cornification while lower doses ( $5 \mu \mathrm{g}$ daily) resulted in ovary-dependent cornification (Kimura, Basu \& Nandi, 1967). The ovary-independent type was related to direct effects of oestrogen in the target organ (Takasugi, Kimura \& Mori, 1970) while the ovary-dependent type was ascribed to a changed ovarian function, in turn a result of failure of the normal cyclic LH peak (Gorski, Harlan \& Christensen, 1977). Beside permanent vaginal cornification, neonatal oestrogen treatment results in the occurrence in the upper part of the vagina and in the uterine cervix of a heterotopic columnar epithelium which after puberty develops into adenosis and later into morphological malignancy (Forsberg \& Kalland, 1981). This progression has been shown to be ovary-dependent. Natural (oestradiol-17 $\beta$ ) and synthetic (diethylstilboestrol, DES) oestrogens both induce persistent vaginal cornification and adenosis but a further progression has only been observed after DES treatment (Forsberg \& Kalland, 1981).

When mice are treated neonatally with oestrogens, their ovaries as adults are characterized by absence of corpora lutea, presence of follicles in various stages fof development, and hyperplasia $04: 39: 09 \mathrm{Am}$ 
and hypertrophy of the interstitial tissue (Takasugi \& Bern, 1964; Kimura et al., 1967; Forsberg, 1969; Mori, 1979). The interstitial cells are characterized by their large size and clear cytoplasm.

Granulosa cells, interstitial glandular cells, theca cells, and the cells of the corpus luteum form an interacting system for the synthesis of ovarian steroids (Falck, 1959). Because corpora lutea are lacking in neonatally oestrogen-treated mice, the pattern of ovarian steroid synthesis might be abnormal. Oestrogens inhibit the $\Delta^{5}-3 \beta$-hydroxysteroid dehydrogenase- $\Delta^{5}-\Delta^{4}$-isomerase complex which is responsible for conversion of $\Delta^{5}$ to $\Delta^{4}$ steroids (Goldman \& Bongiovanni, 1967; Goldman, 1974; Spona, 1982, 1983).

The aim of the present study was to investigate steroid synthesis by the ovaries of female mice treated neonatally with DES. In most earlier experiments high doses of DES have been used in the neonatal period ( $5 \mu \mathrm{g} / \mathrm{day})$. Dose-response studies on the effects on ovarian morphology and ovarian steroid synthesis were therefore undertaken.

\section{Materials and Methods}

Animals. Mice belonging to an NMRI stock were used in most experiments. Inbred NMRI mice (breeding couples were a kind gift from Professor von Deimling, Pathologisches Institut, Freiburg, West Germany) from a stock kept by strict brother-to-sister mating were used for grafting experiments. All animals were fed a standard pellet diet and given water ad libitum. They were kept at constant temperature and humidity and in a 12-h light-12-h dark cycle. When pregnant, the females were put in separate cages to give birth. Within $24 \mathrm{~h}$ after birth, females from different litters were pooled and every foster mother was allowed to feed 6-9 female young. The young were weaned at the age of 1 month.

Treatment of animals. An appropriate amount of diethylstilboestrol (DES) or its biologically inactive molecular variant trans-stilbene (both from Sigma Chemicals, St Louis, MO, U.S.A.) were dissolved in a minimal amount of $96 \%$ ethanol and olive oil. The volume injected was $0.025 \mathrm{ml}$ and the doses varied from $5 \mu \mathrm{g}$ to $10^{-6} \mu \mathrm{g}$ DES per day. The young were given one single subcutaneous injection on each of the 5 days after birth. The first injection was given within $24 \mathrm{~h}$ after birth.

Vaginal smears were prepared from 8-week-old females at 16:00-17:00 h and studied for different phases of the oestrous cycle (oestrus, dioestrus and pro-oestrus). Some females were ovariectomized at 8 weeks and killed 8 days later.

Grafting experiments. Inbred females were treated with $5 \mu \mathrm{g}$ DES or $0.025 \mathrm{ml}$ olive oil for the first 5 days after birth. At the age of 4 weeks, one ovary from a control female was grafted under the kidney capsule of a DES-treated female of the same age. The operation took place under ether anaesthesia and the host's own ovaries were removed at the same time. Reciprocal transplantations (ovary from DES-treated female to control female) were done in an identical way. The females were killed 8 weeks after the transplantation.

Histological techniques. After fixation in Bouin's fluid, the preparations (ovaries and cervicovaginal tract) were dehydrated in ethanol and embedded in paraffin wax. Sections were cut at $7 \mu \mathrm{m}$. All preparations were serially sectioned. The cervicovaginal tract was sectioned transversely. The sections were stained in haematoxylin and eosin.

Steroids and chemicals. $\left[7-{ }^{3} \mathrm{H}(\mathrm{N})\right.$ Pregnenolone (sp.act. $\left.19 \cdot 3 \mathrm{Ci} / \mathrm{mmol}\right),\left[1,2,6,7-{ }^{3} \mathrm{H}(\mathrm{N})\right]$ progesterone (sp.act. $115 \mathrm{Ci} / \mathrm{mmol}),\left[1,2-{ }^{3} \mathrm{H}(\mathrm{N})\right] 20 \alpha$-hydroxypregn-4-ene-3-one (20 $\alpha$-dihydroprogesterone; sp.act. $57 \cdot 5 \mathrm{Ci} / \mathrm{mmol}$ ) and $\left[1,2,6,7-{ }^{3} \mathrm{H}(\mathrm{N})\right]$ testosterone (sp.act. $102 \mathrm{Ci} / \mathrm{mmol}$ ) were all from $\mathrm{New}$ England Nuclear, Boston, MA, U.S.A. $17 \alpha-$ Hydroxy-[1,2,6,7- $\left.{ }^{3} \mathrm{H}(\mathrm{N})\right]$ progesterone (sp.act. 55 $\mathrm{Ci} / \mathrm{mmol}$ ) and $\left[1,2,6,7-{ }^{3} \mathrm{H}\right]$ androst-4-ene-3,17-dione (androstenedione, sp.act. $97 \mathrm{Ci} / \mathrm{mmol}$ ) were from Amersham International Ltd, Amersham, Bucks, U.K. After evaporation of the solution 
medium (toluene-ethanol, benzene-ethanol or benzene) the radioactive isotopes were dissolved in ethanol to a final concentration of $222000 \mathrm{~d} . \mathrm{p} . \mathrm{m}$. in $10 \mu \mathrm{l}$ ethanol. The purity of $\left[{ }^{3} \mathrm{H}\right]$ pregnenolone was checked on thin-layer chromatography during the experimental period and was always found to be more than $90 \%$. A further $10 \%$ could be accounted for by an unidentified contaminant.

$\left[4-{ }^{14} \mathrm{C}\right]$ Progesterone (sp.act. $56 \mathrm{mCi} / \mathrm{mmol}$ ), $\left[4^{-14} \mathrm{C}\right]$ testosterone (sp.act. $58 \mathrm{mCi} / \mathrm{mmol}$ ), and [4-14 C]androst-4-ene-3,17-dione (sp.act. $59 \mathrm{mCi} / \mathrm{mmol}$ ) were all from Amersham International Ltd and $17 \alpha-\left[4-{ }^{14} \mathrm{C}\right]$ hydroxyprogesterone (sp.act. $50 \mathrm{mCi} / \mathrm{mmol}$ ) was from New England Nuclear. After evaporation of the solution medium (toluene or benzene-ethanol) the ${ }^{14} \mathrm{C}$-labelled steroids were dissolved in ethanol at a concentration of 27750 d.p.m./10 $\mu$ l ethanol.

The following non-radioactive steroids were used (all from Sigma Chemicals): $\Delta^{5}$-pregnen-3 $\beta$ ol-20-one (pregnenolone), $\Delta^{4}$-pregnen-3,20-dione (progesterone), $\Delta^{4}$-pregnen-17 $\alpha$-ol-3,20-dione

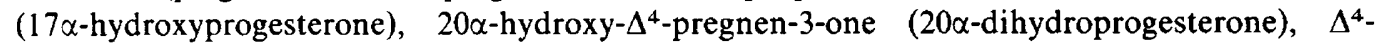
androstene-3,17-dione (androstenedione), $\Delta^{5}$-pregnen-3 $\beta, 17 \alpha$-dihydroxy-20-one (17 $\alpha$-hydroxypregnenolone), $\Delta^{5}$-androsten-3 $\beta$-ol-17-one (dehydroepiandrosterone), $\Lambda^{4}$-androsten-7 $\beta$-ol-3-one (testosterone), $5 \alpha$-androstan-3 $\alpha$-ol-17-one (androsterone), 1,3,5(10)-oestratrien-3,17 $\beta$-diol (oestradiol-17 $\beta$ ), 1,3,5(10)-oestratrien-3-ol-17-one (oestrone) and 1,3,5(10)-oestratrien-3,16 $\alpha, 17 \beta$-triol (oestriol). They were all dissolved in ethanol at a concentration of $5 \mathrm{mg} / \mathrm{ml}$.

Glucose 6-phosphate (monosodium salt), glucose 6-phosphate dehydrogenase (G-6PDH, type IX, from Bakers yeast), $\beta$-nicotinamide adenine dinucleotide phosphate (free acid, NADP) were from Sigma Chemicals. Ethyl acetate (analytical grade), benzene (for chromatography), methanol (for chromatography) and diethyl ether (dried, analytical grade) were all from Merck AG, Darmstadt, West Germany.

Incubation of ovaries and extraction of steroids. The ovaries were carefully dissected free from the surrounding bursa, weighed, and put into ice-cold Medium 199 (Statens Bakteriologiska Laboratorium, Stockholm, Sweden). They were homogenized for $15 \mathrm{sec}$ while cooling on ice (Polytron Homogenizer).

In initial kinetic studies on the relationship between amount of ${ }^{3} \mathrm{H}$-steroid metabolite recovered and amount of $\left[{ }^{3} \mathrm{H}\right]$ pregnenolone substrate added (110 000-880 000 d.p.m.), incubation time (10$120 \mathrm{~min}$ ), and dilution of homogenate $(1: 1-1: 32)$, several 2-ml homogenates of 2 ovaries were pooled. This pool was divided into an appropriate number of $2-\mathrm{ml}$ fractions to allow a whole kinetic experiment to be run on the same pool of homogenate, avoiding inter-female variations. For the substrate studies, 4 homogenates were pooled and for the time studies 5 homogenates. For the dilution experiments, 2 homogenates were used and a $2-\mathrm{ml}$ fraction of this pool was $1: 1$ in the dilution series, while the other $2-\mathrm{ml}$ fraction was used for further dilution and at each step the volume was corrected to $2 \mathrm{ml}$. Based on the results from these experiments, the optimal incubation conditions for later experiments were defined as incubation of homogenate representing one ovary in $2 \mathrm{ml}$ medium for $60 \mathrm{~min}$ in the presence of 440000 d.p.m. $\left[{ }^{3} \mathrm{H}\right]$ pregnenolone $(10 \cdot 3 \mathrm{pmol})$. Duplicate results were thus obtained from every female, except in grafting experiments in which only one ovary was studied from every female.

Before adding a $2-\mathrm{ml}$ homogenate to the $\left[{ }^{3} \mathrm{H}\right]$ pregnenolone, the solution medium for the steroid (20 $\mu$ l ethanol) was evaporated. The homogenate was further enriched with $200 \mu$ glucose 6phosphate $(50 \mu \mathrm{M}), 200 \mu \mathrm{l}$ NADP $(50 \mu \mathrm{M})$ and $100 \mu$ l glucose 6 -phosphate dehydrogenase (5 units). All the cofactors were dissolved in buffered saline $\left(3 \mathrm{~mm}-\mathrm{NaH}_{2} \mathrm{PO}_{4}, 6 \mathrm{~mm}-\mathrm{Na}_{2} \mathrm{HPO}_{4}, 150 \mathrm{~mm}\right.$ $\mathrm{NaCl} ; \mathrm{pH} 7$ ).

Incubation took place at $37^{\circ} \mathrm{C}$ in an atmosphere of $95 \%$ air and $5 \% \mathrm{CO}_{2}$ and was interrupted by addition of $3 \mathrm{ml}$ ethyl acetate. After shaking at room temperature during the night, the tubes were centrifuged at $2000 \mathrm{~g}_{\mathrm{av}}$ for $10 \mathrm{~min}$ and the ethyl acetate fraction transferred to new test tubes. The water phase was re-shaken twice, each time with $3 \mathrm{ml}$ ethyl acetate, and centrifuged as above. The result was a pool of $9 \mathrm{ml}$ ethyl acetate with extracted steroids. This pool contained more than $94 \%$ of the radioactivity initially added to the homogenate. The ethyl acetate was evaporated and the steroids redissolved in $100 \mu$ l ethanol. 
Thin-layer chromatography (t.l.c.). Silica gel plates $60 \mathrm{~F}_{254}$, pre-coated, $20 \times 20 \mathrm{~cm}$, thickness $0.25 \mathrm{~mm}$ (E. Merck, Darmstadt, West Germany) were used. Unlabelled reference steroids and the $100 \mu$ ethanol solution of extracted steroids from the ovarian homogenate were added to the plates and run in a two-dimensional t.l.c. system as described by Bicknell \& Gower (1971). The plates were run twice in a benzene-ether system $(9: 1 \mathrm{v} / \mathrm{v})$; after turning through $90^{\circ}$, the eluant was benzene-methanol $(9: 1 \mathrm{v} / \mathrm{v})$. The carrier steroids were located with u.v. light and $4 \%$ sulphuric acid in ethanol. Areas containing visible steroids were scraped off and transferred to scintillation vials. After adding $3 \mathrm{ml}$ scintillation fluid ( $4 \mathrm{~g}$ PPO, $0 \cdot 3 \mathrm{~g}$ POPOP in $1000 \mathrm{ml}$ toluene; PPO and POPOP from Packard Instrument Inc, Downers Grow, IL, U.S.A.) radioactivity was measured in a Packard scintillation counter, model 2450. After correction for counting efficiency and differences in efficiency of the scintillation fluid to extract different steroids, all results were expressed as d.p.m.

Experimental loss during extraction and chromatography was estimated by adding ${ }^{14} \mathrm{C}$-labelled steroids to the homogenate immediately before extraction with ethyl acetate. The loss was $<12 \%$ and did not vary significantly between different steroids. The experimental results were corrected for this loss.

Recrystallization. The identity of the steroids in different t.l.c. areas was confirmed in recrystallization experiments. Material scraped from the t.l.c. plates and containing tentative ${ }^{3} \mathrm{H}$ steroid was extracted in ethyl acetate and mixed with $50 \mathrm{mg}$ of the corresponding unlabelled steroid and ${ }^{14} \mathrm{C}$-steroid. The mixture was recrystallized to constant specific activity. For $20 \alpha$-dihydroprogesterone, recrystallization took place to constant specific activity per mg crystal. When recrystallization indicated heterogeneity of steroids in a t.l.c. area, this area was extracted with ethyl acetate and the extracted steroid was subjected to re-chromatography in a benzene-methanol $(9: 1 \mathrm{v} / \mathrm{v})$ system. The areas with radioactivity were extracted and recrystallization done as described above. The same system was used for androsterone identification.

\section{Results \\ Histological studies \\ Ovarian histology. A daily $10-\mu \mathrm{g}$ dose of trans-stilbene for 5 days after birth $(\mathrm{N}=5)$ had no effect on ovarian histology at 8 weeks of age. In these animals and in 9 treated with olive oil only, the histology of the ovaries was similar to that of normal females. There were large number of corpora lutea and follicles at various stages of development (Pl. 1, Fig. 1). The interstitial tissue}

\section{PLATE 1}

Fig. 1. Low-power magnification of a section from a control ovary. The most prominent tissue compartments are the follicles and the corpora lutea. $\times 20$.

Fig. 2. Low-power magnification of an ovarian section from a female injected with $10^{-3} \mu \mathrm{g}$ DES in the neonatal period. No corpora lutea are seen. $\times 20$.

Fig. 3. High-power magnification of the interstitial tissue cells in a control ovary. $\times 350$.

Fig. 4. High-power magnification of the interstitial tissue cells from the same ovary as shown in

Fig. 3. The cells are large and the cytoplasm clear. $\times 350$.

Fig. 5. Microphotograph showing the high cornified squamous vaginal epithelium in 8-weekold females injected with $5 \mu \mathrm{g}$ DES neonatally. $\times 80$.

Fig. 6. Eight days after ovariectomy of 8-week-old females injected with $5 \mu \mathrm{g}$ DES neonatally, the vaginal epithelium is of a non-cornified squamous type with leucocytes in the superficial layer. $\times 80$.

Fig. 7. Section of the vaginal epithelium from a female treated as described in Fig. 6 but given a daily dose of $10^{-3} \mu \mathrm{g}$ DES in the neonatal period. The epithelium is low with a superficial layer of mucified cells infiltrated with leucocytes. $\times 80$ 

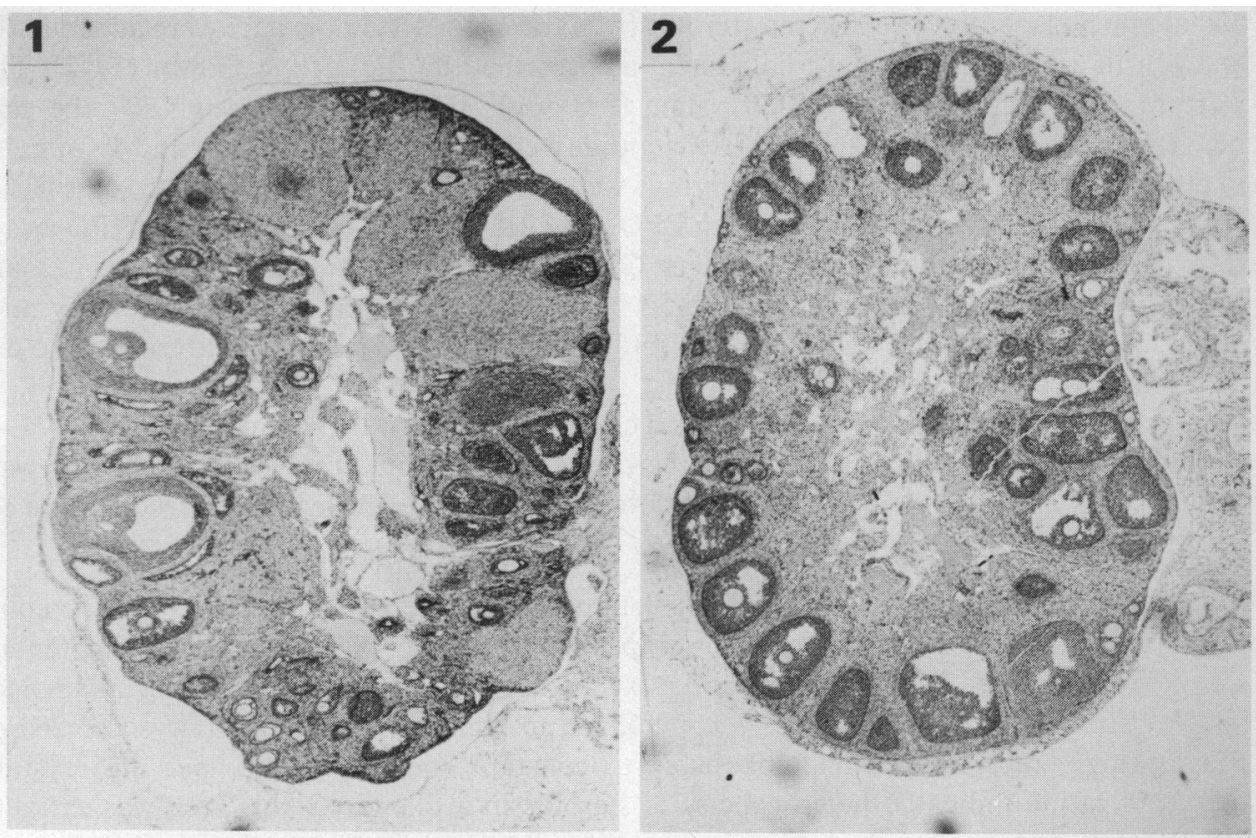

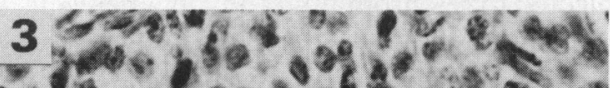

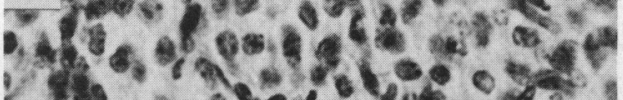
(20)

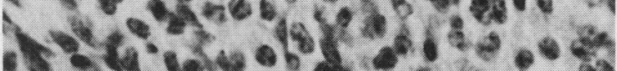

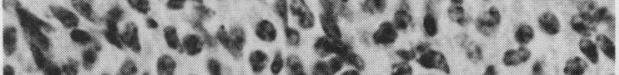

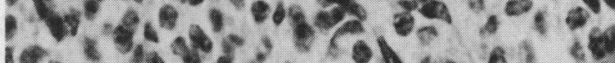
Ifot $-x^{2}$.

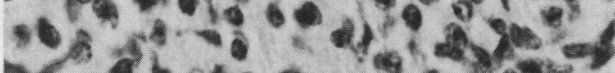

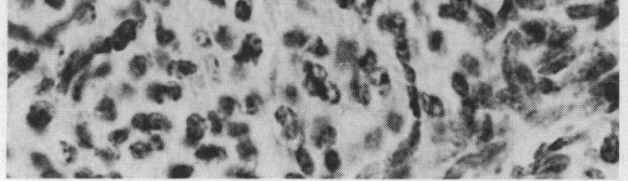
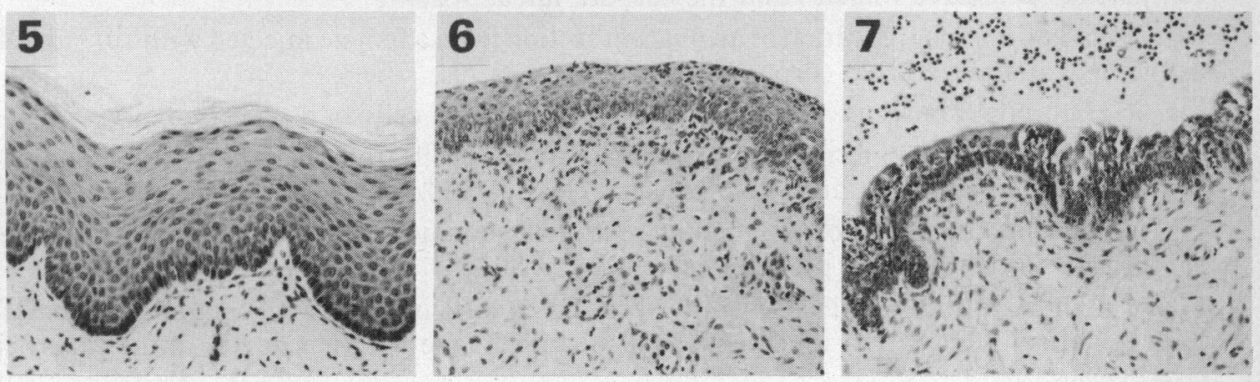
consisted of small polygonal cells with a palely stained cytoplasm (Pl. 1, Fig. 3). The cells were arranged in nodular or cord-like formations.

In 8 females treated with $10^{-5} \mu \mathrm{g}$ DES for 5 days after birth, the follicles, corpora lutea and interstitial tissue appeared similar to those in controls. None of the ovaries from 8 females treated with a daily dose of $10^{-4} \mu \mathrm{g}$ or higher doses $\left(10^{-3} \mu \mathrm{g}, 9\right.$ females; $10^{-2} \mu \mathrm{g}, 7$ females; $10^{-1} \mu \mathrm{g}, 9$ females; $1 \mu \mathrm{g}, 8$ females; $5 \mu \mathrm{g}, 8$ females) contained any corpora lutea (PI. 1, Fig. 2). The crosssections from these ovaries were dominated by interstitial tissue and follicles. The interstitial tissue cells were arranged in nodular or cord-like formations, as described for controls, but the cytoplasmic-nuclear ratio was higher and the cytoplasm was clear (Pl. 1, Fig. 4).

Four ovaries from females treated with 1 or $5 \mu \mathrm{g}$ DES had cysts of various sizes; the lumen was filled with red blood corpuscles. The cyst wall had no characteristic histology to indicate the origin of these cysts.

Ovarian wet weight. An analysis of variance (animals and cycle phases as variables) did not indicate any significant difference in ovarian weight between the three phases of the oestrous cycle $(\mathrm{F}=1.19$ for 2 and 14 d.f.). The mean \pm s.e.m. of the control ovaries was $7.8 \pm 0.6 \mathrm{mg}(\mathrm{N}=$ 34) while that for ovaries from females injected with a daily dose of $5 \mu \mathrm{g}$ DES in the neonatal period was $5.6 \pm 0.2 \mathrm{mg}(\mathrm{N}=50)(P<0.001$, Student's $t$ test after correction for difference in error variance).

Ovary-dependency of vaginal epithelium. Females injected with 5 or $10^{-3} \mu \mathrm{g}$ DES daily for the first 5 days after birth were ovariectomized at the age of 8 weeks and killed 8 days later. Nonovariectomized females from the same litters were killed at the same time. The cervicovaginal epithelium of the latter females was high and cornified. Patches of non-cornified regions were infiltrated with leucocytes, especially in the superficial cell layers. The vaginal epithelium of the DES- and ovariectomized females was quite different: animals injected with $10^{-3} \mu \mathrm{g}$ DES had an epithelium similar to that in untreated ovariectomized females or low and mucified, while in animals treated with $5 \mu \mathrm{g}$ DES, it was of a low non-cornified squamous type. A prominent trait with both doses was the pronounced infiltration with leucocytes (Pl. 1, Figs 5, 6, 7).

Histology of grafted ovaries. The grafted ovaries survived well and no histological evidence for an inflammatory response was seen. Ovaries from DES-treated females grafted into control females had normal histological morphology with follicles, corpora lutea and normal interstitial cells. However, ovaries from control females grafted into DES-treated females had a seemingly normal follicle structure but lacked corpora lutea. The interstititial tissue was of the same type as described above for DES-treated females.

\section{In-vitro studies on ovarian steroid synthesis}

Kinetic studies. The typical separation pattern on a t.l.c. plate is shown in Text-fig. 1.

Kinetic studies were run on homogenates of ovaries from females in all the three cycle phases studied as well as on homogenates from DES-treated females. All experiments were repeated 2 or 3 times. Results from these studies were plotted for progesterone, 17 $\alpha$-hydroxyprogesterone, androstenedione and testosterone. Representative graphs from different cycle phases and steroids are shown in Text-figs 2-4. There were no obvious differences in general shape of the kinetic graphs related to the oestrous cycle (a complete set of data for the different stages of the oestrous cycle and different steroids is not included in Text-figs 2-4).

There was a linear relationship between increasing amounts of $\left[{ }^{3} \mathrm{H}\right]$ pregnenolone added to control homogenates and radioactivity recovered from most of the reference areas but the slope of the lines varied (Text-fig. 2a). An exception was testosterone for which the graph tended to be curvilinear (Text-fig. 2b). With homogenates of DES-exposed ovaries ( $5 \mu \mathrm{g}$ DES) the results were different. The graphs for radioactivity in the areas tentatively taken to represent androstenedione and $17 \alpha$-hydroxyprogesterone flattened out (Text-fig. 2a); for testosterone, the response became a straight line (Text-fig. 2b); for progesterone, the increase was linear. The radioactivity in the $17 \alpha-$ 


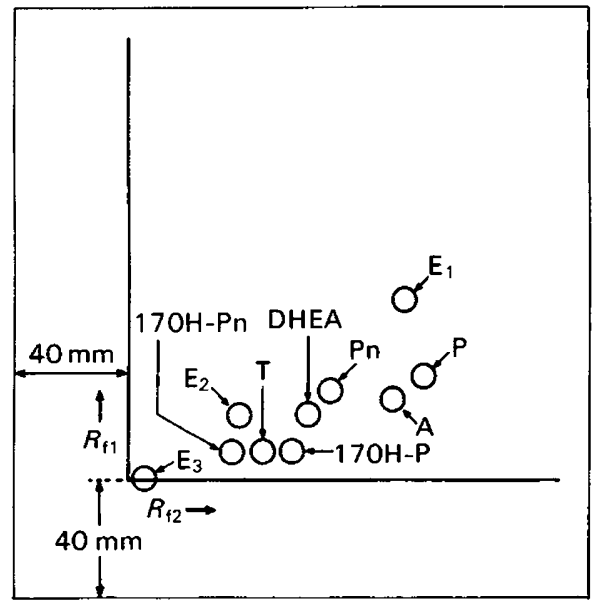

Text-fig. 1. Schematic drawing showing the typical localization of the different steroids studied on a t.l.c. plate, using the two-dimensional t.l.c. technique. $A$, androstenedione; $E_{1}$, oestrone; $E_{2}$, oestradiol; $E_{3}$, oestriol; DHEA, dehydroepiandrosterone; 17OH-P, 17 $\alpha$-hydroxyprogesterone; Pn, pregnenolone; $17 \mathrm{OH}-\mathrm{Pn}, 17 \alpha$-hydroxypregnenolone; $\mathrm{P}$, progesterone; $\mathrm{T}$, testosterone.
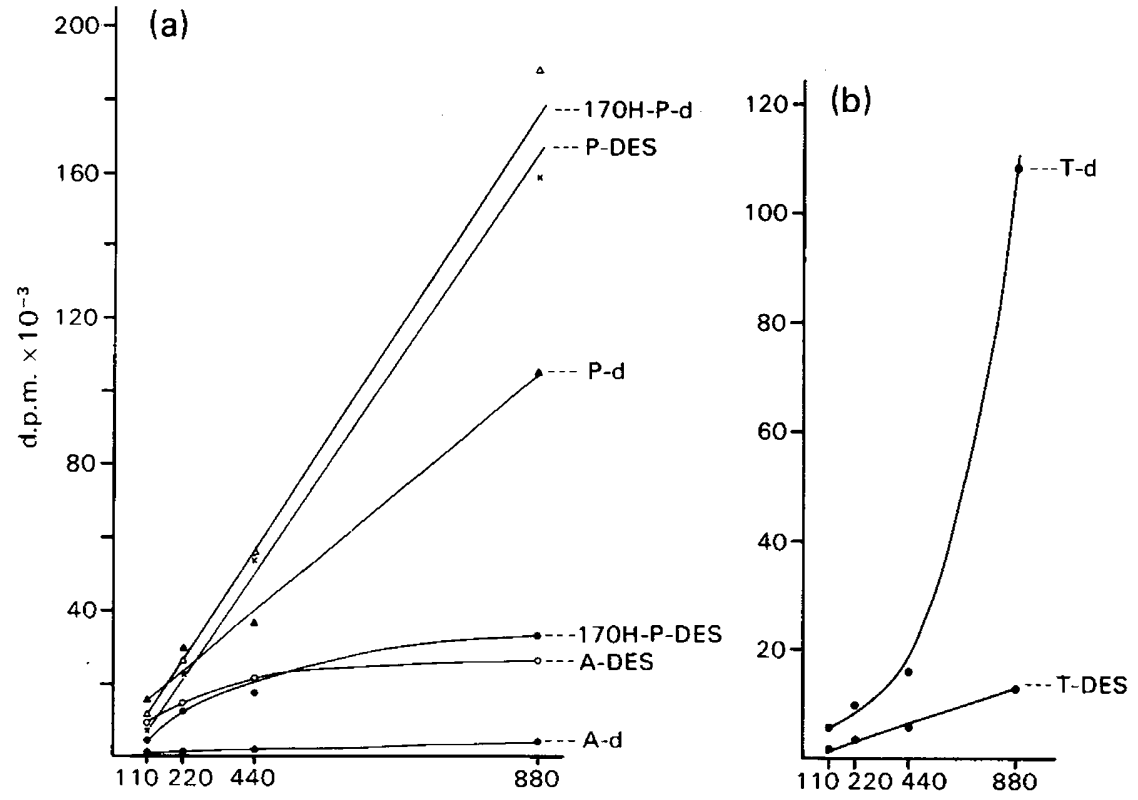

$\left[{ }^{3} \mathrm{H}\right]$ Pregnenolone (d.p.m. $\times 10^{-3}$ )

Text-fig. 2. Graphs showing the relationship between increasing amounts of $\left[{ }^{3} \mathrm{H}\right]$ pregnenolone added to the ovarian homogenate and the amount of radioactivity recovered from different reference areas on the t.l.c. plates. A, androstenedione; P, progesterone; $17 \mathrm{OH}-\mathrm{P}, 17 \alpha-$ hydroxyprogesterone; $T$, testosterone; DES: homogenate of ovaries from females treated with $5 \mu \mathrm{g}$ DES for 5 days after birth; $\mathrm{d}, \mathrm{o}, \mathrm{p}$ : homogenates of ovaries from females in dioestrus, oestrus or pro-oestrus phase of the cycle, i.e. $170 \mathrm{H}-\mathrm{P}-\mathrm{d}$ means the graph for $17 \alpha$-hydroxyprogesterone in an homogenate from a female in dioestrus. 


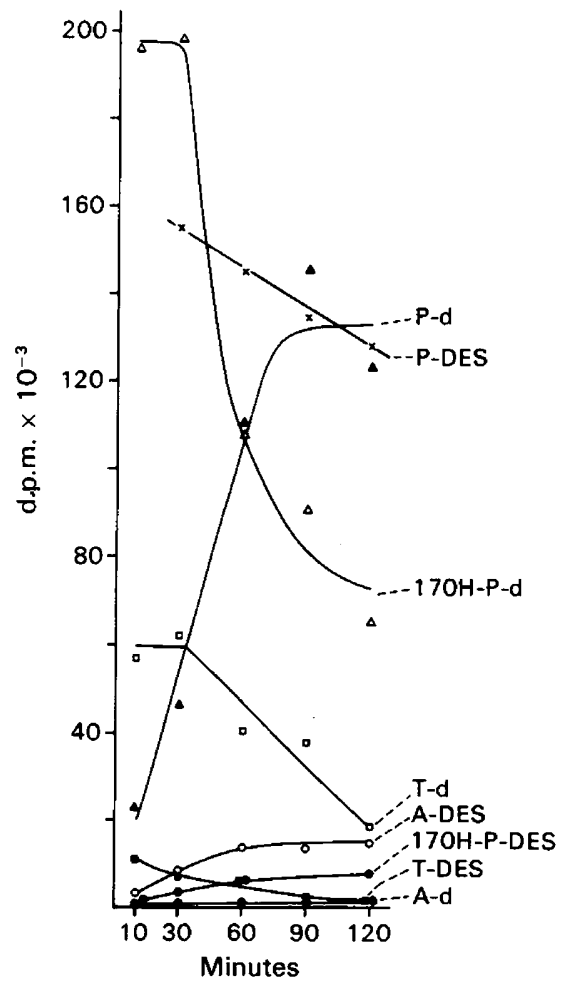

Text-fig. 3. Graph of the relationship between amount of radioactivity recovered and increasing incubation time. For abbreviations and explanations, see Text-fig. 2.
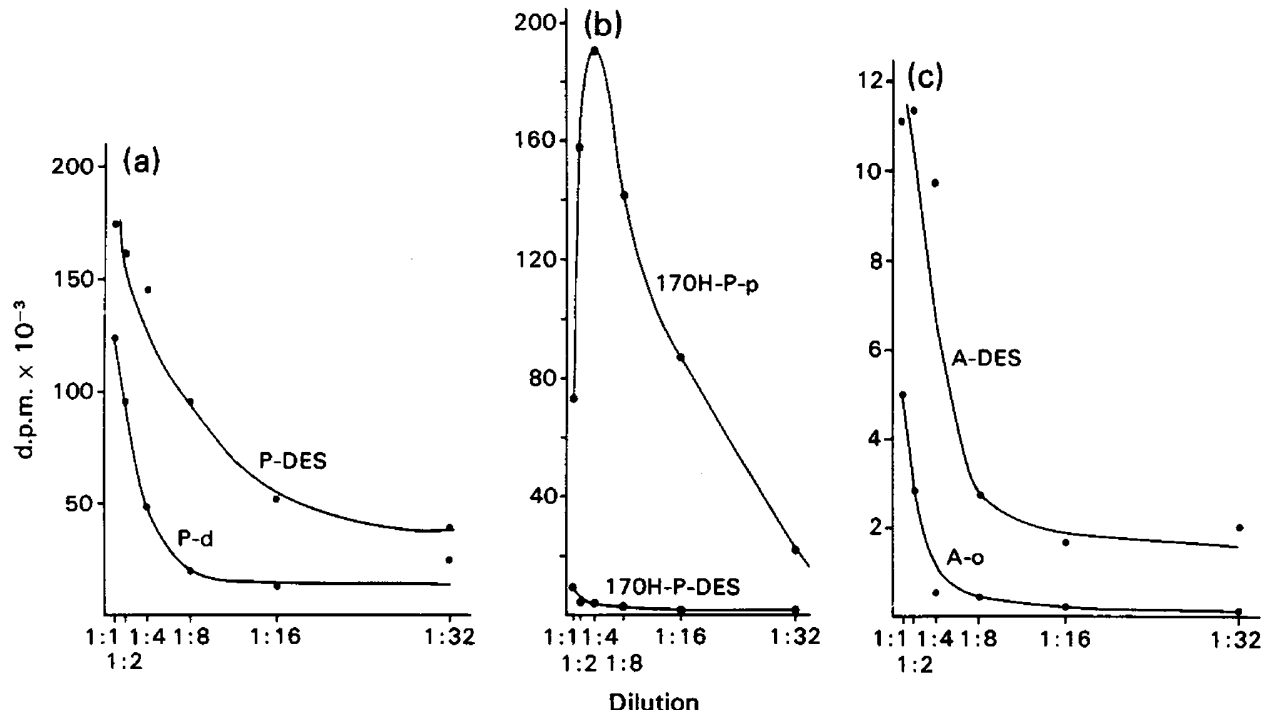

Text-fig. 4. Graphs showing variations in the amount of radioactivity recovered as related to dilution of the homogenate. For abbreviations and explanations, see Text-fig. 2. 
hydroxyprogesterone and testosterone areas was higher for control homogenates compared with homogenates of DES-exposed ovaries but that for androstenedione and progesterone areas was higher for DES-homogenates than controls (except for progesterone at the lowest levels of substrate used).

With respect to time, the radioactivity taken to represent progesterone in control homogenates increased steeply until $90 \mathrm{~min}$, and then flattened out (Text-fig. 3). DES-exposed ovaries had a high initial progesterone production. The radioactivity in the $17 \alpha$-hydroxyprogesterone area was low for DES-homogenates; it was considerably higher for controls but, after 30 min incubation, it decreased with time. The graphs for androstenedione and testosterone also showed differences between homogenates of control and DES-treated ovaries.

With increasing dilution of the homogenates, the radioactivity in the different plate areas (except that representing 17 $\alpha$-hydroxyprogesterone) decreased (Text-fig. 4). The general shape of the androstenedione, progesterone and testosterone graphs was similar for control and DEShomogenates but the level of the lines varied. The graph representing $17 \alpha$-hydroxyprogesterone in control homogenates had an initial steep increase and later decreased; it was quite different from that representing $17 \alpha$-hydroxyprogesterone in DES-homogenates.

Taken together, the results described above indicate that there are differences as regards kinetic behaviour of radioactivity, tentatively taken to represent the steroids mentioned, between control and DES-treated ovaries. Based on these results, the optimal incubation conditions were defined for all the following experiments (see 'Methods').

General comments on the t.l.c. results under optimal incubation conditions. A maximum of $70 \%$ of the radioactivity initially added to the starting point on the t.l.c. plates could be accounted for by the total radioactivity in the 10 reference areas on the plates. The different steroids could be divided into a high activity group and a low activity group. Included in the latter were $17 \alpha$-hydroxypregnenolone, dehydroepiandrosterone, oestrone, oestradiol and oestriol with $2-8 \%$ of the total radioactivity added represented in each area, respectively. Only insignificant amounts (about $1 \%$ ) of androsterone were found. The low-activity group will be the subject for further studies and is not included in the following presentation. The main interest was devoted to the four steroids (progesterone, 17 $\alpha$-hydroxyprogesterone, androstenedione and testosterone) in the high-activity group. The results indicate that the $\Delta^{4}$ synthetic pathway from pregnenolone was the preferred one and this was the same for control and DES-exposed ovaries. A maximum of $18 \%$ of the total radioactivity added to the homogenate was recovered from the area representing pregnenolone; in the majority of incubations the percentage was less than $5 \%$.

Recrystallization experiments. The homogeneity of the ${ }^{3} \mathrm{H}$-steroids in the different t.l.c. areas tentatively taken to represent progesterone, 17 $\alpha$-hydroxyprogesterone, androstenedione and testosterone was studied in recrystallization experiments. These were run on material from females in different phases of the oestrous cycle as well as on material from DES-exposed ovaries. The results are presented in Table 1 . More than $91 \%$ of the radioactivity in the progesterone and androstenedione areas represented these ${ }^{3} \mathrm{H}$-steroids and this was true for all materials. In contrast to this, the radioactivity within the testosterone and, above all, the $17 \alpha$-hydroxyprogesterone areas was a more heterogeneous mixture of ${ }^{3} \mathrm{H}$-steroids. Within the $17 \alpha$-hydroxyprogesterone area, the heterogeneity was related to the cycle phase and was less in material from pro-oestrous animals than in that from dioestrous, oestrous or DES-treated mice.

In separate experiments we demonstrated that $17 \alpha$-hydroxyprogesterone and $20 \alpha$-dihydroprogesterone co-migrated in our two-dimensional t.l.c. system and the suspicion arose that $20 \alpha-$ dihydroprogesterone was responsible for the heterogeneity within the $17 \alpha$-hydroxyprogesterone area. Because of the position on the plates (Text-fig. 1), the same steroids could also be possible candidates for contamination within the testosterone area. After extraction of the steroids within the $17 \alpha$-hydroxyprogesterone and testosterone areas and re-chromatography in benzene-methanol on a second plate, a further separation was obtained. The results are shown in Table 2 . The material from the $17 \alpha$-hydroxyprogesterone area on the first t.l.c. plate contained about the same 
Table 1. Characterization of ${ }^{3} \mathrm{H}$-steroid metabolites after incubation of mouse ovarian homogenates with $\left[{ }^{3} \mathrm{H}\right]$ pregnenolone and first separation on t.l.c.

\begin{tabular}{|c|c|c|c|c|c|c|c|c|}
\hline $\begin{array}{l}\text { Steroid } \\
\text { area }\end{array}$ & $\begin{array}{l}\text { State of } \\
\text { mouse }\end{array}$ & $\begin{array}{l}\text { t.l.c. } \\
\text { eluate }\end{array}$ & ML 2 & ML 3 & ML 4 & ML 5 & $\begin{array}{l}\text { Final } \\
\text { crystal }\end{array}$ & $\%$ \\
\hline Progesterone & $\begin{array}{l}\text { Pro-oestrous } \\
\text { Oestrous } \\
\text { Dioestrous } \\
\text { DES-treated }\end{array}$ & $\begin{array}{r}1.84 \\
10 \cdot 29 \\
2.97 \\
0.90\end{array}$ & $\begin{array}{r}1 \cdot 80 \\
10 \cdot 20 \\
2.90 \\
0.89\end{array}$ & $\begin{array}{r}1 \cdot 76 \\
10 \cdot 17 \\
2 \cdot 81 \\
0.88\end{array}$ & $\begin{array}{l}1.75 \\
9.84 \\
2.80 \\
0.88\end{array}$ & $\begin{array}{l}1 \cdot 75 \\
9 \cdot 57 \\
2 \cdot 75 \\
0.86\end{array}$ & $\begin{array}{l}1 \cdot 75 \\
9 \cdot 56 \\
2 \cdot 75 \\
0.85\end{array}$ & $\begin{array}{l}95 \\
93 \\
93 \\
95\end{array}$ \\
\hline Androstenedione & $\begin{array}{l}\text { Pro-oestrous } \\
\text { Oestrous } \\
\text { Dioestrous } \\
\text { DES-treated }\end{array}$ & $\begin{array}{l}0.32 \\
0.43 \\
0.34 \\
2 \cdot 45\end{array}$ & $\begin{array}{l}0 \cdot 32 \\
0 \cdot 41 \\
0 \cdot 34 \\
2 \cdot 41\end{array}$ & $\begin{array}{l}0.31 \\
0.41 \\
0.33 \\
2.36\end{array}$ & $\begin{array}{l}0.31 \\
0.41 \\
0.32 \\
2.34\end{array}$ & $\begin{array}{l}0.30 \\
0.40 \\
0 \cdot 32 \\
2 \cdot 33\end{array}$ & $\begin{array}{l}0.30 \\
0.40 \\
0.32 \\
2 \cdot 33\end{array}$ & $\begin{array}{l}93 \\
92 \\
93 \\
95\end{array}$ \\
\hline 17-hydroxyprogesterone & $\begin{array}{l}\text { Pro-oestrous } \\
\text { Oestrous } \\
\text { Dioestrous } \\
\text { DES-treated }\end{array}$ & $\begin{array}{l}0.51 \\
3.67 \\
1.38 \\
0.81\end{array}$ & $\begin{array}{l}0.49 \\
2.62 \\
1.02 \\
0.58\end{array}$ & $\begin{array}{l}0.49 \\
1.72 \\
0.80 \\
0.46\end{array}$ & $\begin{array}{l}0.46 \\
1.72 \\
0.79 \\
0.36\end{array}$ & $\begin{array}{l}0.46 \\
1.71 \\
0.64 \\
0.36\end{array}$ & $\begin{array}{l}0.45 \\
1.71 \\
0.63 \\
0.35\end{array}$ & $\begin{array}{l}89 \\
47 \\
46 \\
43\end{array}$ \\
\hline Testosterone & $\begin{array}{l}\text { Pro-oestrous } \\
\text { Oestrous } \\
\text { Dioestrous } \\
\text { DES-treated }\end{array}$ & $\begin{array}{l}0.35 \\
1.38 \\
0.59 \\
0.51\end{array}$ & $\begin{array}{l}0.34 \\
1.32 \\
0.58 \\
0.47\end{array}$ & $\begin{array}{l}0.32 \\
1.24 \\
0.54 \\
0.46\end{array}$ & $\begin{array}{l}0.31 \\
1.18 \\
0.51 \\
0.45\end{array}$ & $\begin{array}{l}0.30 \\
1.13 \\
0.49 \\
0.45\end{array}$ & $\begin{array}{l}0.30 \\
1 \cdot 12 \\
0.47 \\
0.44\end{array}$ & $\begin{array}{l}85 \\
82 \\
80 \\
86\end{array}$ \\
\hline
\end{tabular}

${ }^{3} \mathrm{H}$-Steroids were extracted from the area on the t.l.c. plate indicated by the unlabelled reference steroid. After addition of unlabelled reference steroid and ${ }^{14} \mathrm{C}$-steroid, crystallization was started. ${ }^{3} \mathrm{H}:{ }^{14} \mathrm{C}$ quotients are given both for the original eluate and for the different mother liquors (ML) during various recrystallization steps. The quotient in the final crystals were related to the quotient in the t.l.c. eluate and the results are expressed in percentages.

Table 2. Characterization of the ${ }^{3} \mathrm{H}$-steroid metabolite content in the $17 \alpha$-hydroxyprogesterone and testosterone areas from the first two-dimensional t.l.c. run

\begin{tabular}{|c|c|c|c|c|}
\hline \multirow{3}{*}{$\begin{array}{c}\text { State of } \\
\text { mouse }\end{array}$} & \multicolumn{4}{|c|}{ t.l.c. area } \\
\hline & \multicolumn{2}{|c|}{$17 \alpha-$ Hydroxyprogesterone } & \multicolumn{2}{|l|}{ Testosterone } \\
\hline & Steroid & $\%$ & Steroid & $\%$ \\
\hline Pro-oestrous & $\begin{array}{l}17 \alpha-\text { Hydroxyprogesterone } \\
20 \alpha \text {-Dihydroprogesterone } \\
\text { Testosterone }\end{array}$ & $\begin{array}{r}86 \\
12 \\
1\end{array}$ & $\begin{array}{l}\text { Testosterone } \\
17 \alpha \text {-Hydroxyprogesterone } \\
20 \alpha \text {-Dihydroprogesterone }\end{array}$ & $\begin{array}{r}84 \\
15 \\
1\end{array}$ \\
\hline Oestrous & $\begin{array}{l}17 \alpha \text {-Hydroxyprogesterone } \\
20 \alpha \text {-Dihydroprogesterone } \\
\text { Testosterone }\end{array}$ & $\begin{array}{r}44 \\
53 \\
1\end{array}$ & $\begin{array}{l}\text { Testosterone } \\
17 \alpha \text {-Hydroxyprogesterone } \\
20 \alpha \text {-Dihydroprogesterone }\end{array}$ & $\begin{array}{r}81 \\
16 \\
2\end{array}$ \\
\hline Dioestrous & $\begin{array}{l}17 \alpha \text {-Hydroxyprogesterone } \\
20 \alpha \text {-Dihydroprogesterone } \\
\text { Testosterone }\end{array}$ & $\begin{array}{r}41 \\
56 \\
1\end{array}$ & $\begin{array}{l}\text { Testosterone } \\
17 \alpha \text {-Hydroxyprogesterone } \\
20 \alpha \text {-Dihydroprogesterone }\end{array}$ & $\begin{array}{r}76 \\
21 \\
2\end{array}$ \\
\hline DES-treated & $\begin{array}{l}17 \alpha \text {-Hydroxyprogesterone } \\
20 \alpha \text {-Dihydroprogesterone } \\
\text { Testosterone }\end{array}$ & $\begin{array}{r}41 \\
56 \\
1\end{array}$ & $\begin{array}{l}\text { Testosterone } \\
17 \alpha \text {-Hydroxyprogesterone } \\
20 \alpha \text {-Dihydroprogesterone }\end{array}$ & $\begin{array}{r}86 \\
11 \\
1\end{array}$ \\
\hline
\end{tabular}

Material from the $17 \alpha$-hydroxysteroid and testosterone areas on the first two-dimensional t.l.c. plate was extracted with ethyl acetate and further separated on a second plate in a benzene-methanol system.

proportions of $17 \alpha$-hydroxyprogesterone, $20 \alpha$-dihydroprogesterone, and testosterone in all the materials studied $(41-44 \%, 53-56 \%, 1 \%$, respectively). Contrary to this, material from pro-oestrous females had a greater amount of $17 \alpha$-hydroxyprogesterone $(86 \%)$ and a lesser amount of $20 \alpha$ dihydroprogesterone $(12 \%)$ while the testosterone contamination was insignificant $(1 \%)$. Material from the first testosterone t.l.c. area was contaminated with $17 \alpha$-hydroxyprogesterone (Table 2), 


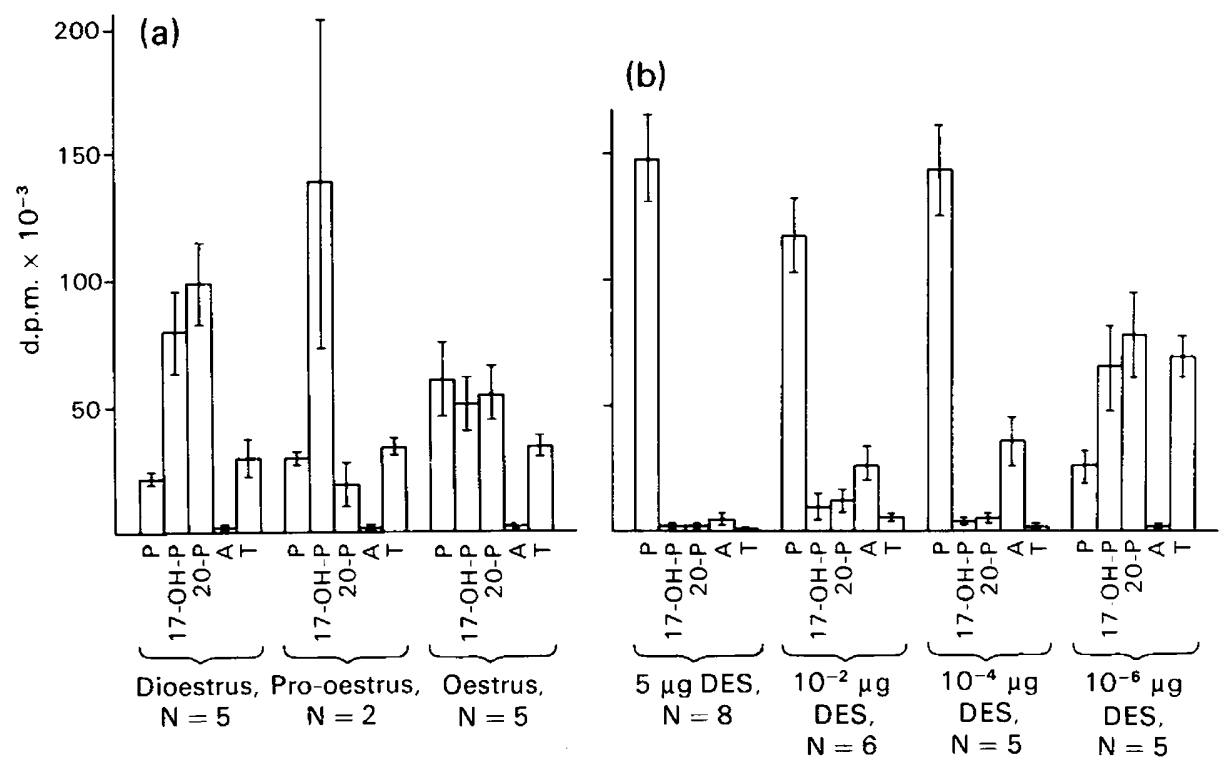

Text-fig. 5. Pattern of ${ }^{3} \mathrm{H}$-steroids in ovarian homogenates from different phases of the oestrous cycle (a) and in females injected with different doses of DES (b). The mean \pm s.e.m. of the means of duplicates are shown for different steroids. P, progesterone; $17-\mathrm{OH}-\mathbf{P}, 17 \alpha$-hydroxyprogesterone; 20-P, 20 $\alpha$-dihydroprogesterone; A, androstenedione; T, testosterone.

with small variations in different materials (11-21\%). Insignificant amounts of $20 \alpha$-dihydroprogesterone were found $(1-2 \%)$. Recrystallization verified the identity of $17 \alpha$-hydroxyprogesterone and $20 \alpha$-dihydroprogesterone in the areas on the second t.l.c. plates $(>90 \%$ remained in the final crystals).

Steroid synthesizing ability of ovarian homogenates from control and DES-treated mice. The results are presented in Text-fig. 5. The radioactivity extracted from the different plate areas after twodimensional t.l.c. was corrected with respect to heterogeneity using the percentage figures given in Table 1 (progesterone and androstenedione) and Table 2 (17 $\alpha$-hydroxyprogesterone, $20 \alpha$-dihydroprogesterone and testosterone).

In control homogenates, the radioactivity representing $\left[{ }^{3} \mathrm{H}\right] 17 \alpha$-hydroxyprogesterone was about 4-fold that for $\left[{ }^{3} \mathrm{H}\right]$ progesterone in dioestrus and pro-oestrus but these ${ }^{3} \mathrm{H}$-steroids reached about the same level in oestrus (Text-fig. 5a). The $\left[{ }^{3} \mathrm{H}\right]$ progesterone level was then about twice that in dioestrus and proestrus. The quotient between $\left[{ }^{3} \mathrm{H}\right] 20 \alpha$-dihydroprogesterone and $\left[{ }^{3} \mathrm{H}\right] 17 \alpha-$ hydroxyprogesterone was considerably lower in pro-oestrus (about $1: 7$ ) than in oestrus or dioestrus (about $1: 1$ ). The levels of $\left[{ }^{3} \mathrm{H}\right]$ testosterone and $\left[{ }^{3} \mathrm{H}\right]$ androstenedione were stable during the cycle but $\left[{ }^{3} \mathrm{H}\right]$ androstenedione was synthesized in small amounts only.

A quite different pattern of ${ }^{3} \mathrm{H}$-steroid metabolites occurred in homogenates of DES-exposed ovaries (Text-fig. $5 b$ ). Within the dose range $5-10^{-4} \mu$ g DES per day, the greatest radioactivity represented $\left[{ }^{3} \mathrm{H}\right]$ progesterone, which was synthesized in a larger amount than in any of the normal stages of the oestrous cycle. In addition to this difference, the levels of $\left[{ }^{3} \mathrm{H}\right] 17 \alpha$-hydroxyprogesterone, $\left[{ }^{3} \mathrm{H}\right] 20 \alpha$-dihydroprogesterone and testosterone were considerably lower in DESexposed homogenates than in control homogenates. On the other hand, DES-exposed homogenates more actively synthesized $\left[{ }^{3} \mathrm{H}\right]$ androstenedione than did control homogenates. For the latter steroid there was a trend to increased levels with reduced DES dose. Daily doses of $10^{-6} \mu \mathrm{g}$ DES did not affect the pattern of ${ }^{3} \mathrm{H}$-steroids formed as compared with control homogenates (Text-fig. $5 \mathrm{~b}$ ). 


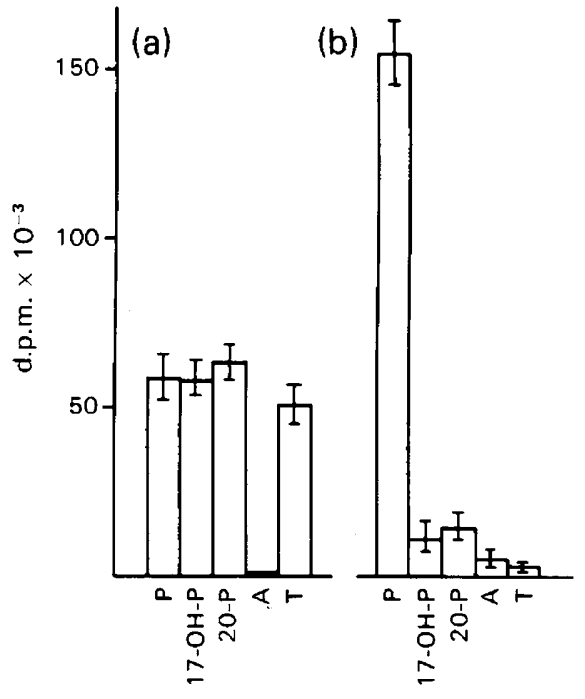

Text-fig. 6. Pattern of ${ }^{3} \mathrm{H}$-steroids synthesized in homogenates of ovaries from (a) DES-treated females grafted into ovariectomized controls and (b) controls into DES-treated females. The means \pm s.e.m. ( $N=3$ for $a ; N=6$ for $b$ ) represent synthesis per 'one-ovary-homogenate'. Abbreviations as in Text-fig. 5.

Table 3. Pool sizes of ${ }^{3} \mathrm{H}$-steroids in mouse ovarian homogenates after incubation for $1 \mathrm{~h}$ in the presence of $\left[{ }^{3} \mathrm{H}\right]$ pregnenolone

\begin{tabular}{|c|c|c|c|c|c|}
\hline \multirow[b]{2}{*}{ Ovary from } & \multicolumn{5}{|c|}{${ }^{3} \mathrm{H}$-Steroid (pmol per 'one-ovary-homogenate') } \\
\hline & Progesterone & $\begin{array}{l}\text { Andro- } \\
\text { stenedione }\end{array}$ & $\begin{array}{l}17 \alpha-\text { Hydroxy- } \\
\text { progesterone }\end{array}$ & $\begin{array}{l}20 \alpha \text {-Dihydro- } \\
\text { progesterone }\end{array}$ & Testosterone \\
\hline Control female at dioestrus & 0.49 & $<0.02$ & 1.92 & $2 \cdot 34$ & $0 \cdot 58$ \\
\hline $\begin{array}{l}\text { DES-treated female } \\
(5 \mu \mathrm{g} \text { DES })\end{array}$ & 3.45 & 0.04 & $<0.02$ & $<0.02$ & $<0.02$ \\
\hline
\end{tabular}

When ovaries from females treated with daily doses of $5 \mu \mathrm{g}$ DES in the neonatal period were transplanted to ovariectomized females, the pattern of ${ }^{3} \mathrm{H}$-steroids formed changed from that characteristic for DES-exposed ovaries to that seen in controls (Text-fig. 6). When ovaries from control females were grafted to ovariectomized but neonatally DES-treated females, the steroid pattern was of the same type as that in ovaries from DES-treated females.

From the results presented in Text-fig. 5, and from the known specific activity of $\left[{ }^{3} \mathrm{H}\right.$ ]pregnenolone, the amounts of radioactive steroids formed in the homogenate of one ovary during incubation for $1 \mathrm{~h}$ were calculated (Table 3).

\section{Discussion}

Daily doses of $10^{-4} \mu \mathrm{g}$ DES, or higher, for the first 5 days after birth resulted in absence of corpora lutea in all ovaries studied from 8-week-old females. The interstitial cells in the same ovaries were large with a clear cytoplasm. This morphology is similar to that earlier described after treating neonatal female mice with high doses (e.g. $5 \mu \mathrm{g}$ ) of oestradiol (Takasugi \& Bern, 1964; Kimura et 
al., 1967; Forsberg, 1969). Treatment of pregnant mice with 0.01-100 $\mu \mathrm{g}$ DES per kg bodyweight from Days 9 to 16 of gestation did not result in any consistent effects on corpora lutea in ovaries from the adult offspring, but some females exposed to the 10 and $100 \mu \mathrm{g}$ doses failed to exhibit these structures (McLachlan, Newbold, Shah, Hogan \& Dixon, 1982). The absence of corpora lutea, at least after neonatal oestrogen treatment, is considered secondary to a distrubance in the hypothalamic-pituitary regulation, resulting in no preovulatory LH peak (Gorski et al., 1977).

Pronounced differences were found in pattern of radioactive steroids synthesized from $\left[{ }^{3} \mathrm{H}\right]$ pregnenolone in ovarian homogenates from females in different phases of the oestrous cycle compared with homogenates of ovaries of mice exposed neonatally to DES $\left(10^{-4} \mu \mathrm{g}\right.$ per day or higher doses) and lacking corpora lutea. Progesterone was the main steroid synthesized in DESexposed ovaries, while 17 $\alpha$-hydroxyprogesterone and $20 \alpha$-dihydroprogesterone were the most prominent ones in control homogenates, their relative amount depending on the phase of the cycle. More $\left[{ }^{3} \mathrm{H}\right]$ androstenedione was formed in DES-exposed homogenates than in control homogenates while the opposite was true for $\left[{ }^{3} \mathrm{H}\right]$ testosterone. These differences cannot be explained by the reduced ovarian weight in DES-treated females. The conclusion is that neonatal DES treatment has no permanent inhibitory effect on the $\Delta^{5}-3 \beta$-hydroxysteroid dehydrogenase- $\Delta^{5}-\Delta^{4}$-isomerase complex to judge from the intense progesterone synthesis in the non-cyclic DES-exposed ovaries.

When ovaries from adult, but prenatally DES-exposed, CD-1 mice were incubated in vitro for $24 \mathrm{~h}$, an increased content (RIA assay) of progesterone, testosterone and oestrogen was found in the medium on a tissue-weight basis but only testosterone remained elevated on a per-ovary basis (Haney, Newbold \& McLachlan, 1984). These results are thus in contrast to those in the present study in which synthesis of tritiated progesterone, 17 $\alpha$-hydroxyprogesterone, 20 $\alpha$-dihydroprogesterone, androstenedione, and testosterone, differed between DES and control ovaries both on a weight and per-ovary basis. The testosterone level was very low in the DES-exposed ovaries in our study. The RIA assay used by Haney et al. (1984) does not necessarily reflect a true steroidogenic capacity but rather a combination of formation and release of preformed steroids. The pattern of steroidogenesis could also be influenced by the long incubation period as suggested from our kinetic studies.

The DES-induced ovarian effects were reversible, as shown by the grafting experiments, and thus secondary to control mechanisms outside the ovary. The results indicate that the enzyme activity most affected was that of $17 \alpha$-hydroxylase and 17/-ol-dehydrogenase. Provided the pituitary gland of adult but neonatally DES-treated mouse females secretes significant amounts of FSH and LH, as it does in neonatally oestrogen-treated rats (Kawashima \& Mori, 1971; Nagasawa, Yanai, Kikuyama \& Mori, 1973; Goomer, Saxena \& Sheth, 1977), the enzyme defects could be considered to be a result of a low but continuous LH secretion. However, direct ovarian effects, perhaps not apparent until later in life, should not be excluded (Mori, 1979). Oestrogens were synthesized from $\left[{ }^{3} \mathrm{H}\right]$ pregnenolone but the conversion was small and must be further analysed. In spite of the pronounced progesterone synthesis in ovaries from DES-treated females, the vaginal epithelium in the same animals was of a high cornified squamous type and its morphology was ovary-dependent. This raises further questions about the circulating levels of progesterone and oestrogens and possible non-ovarian metabolic conversions.

This investigation was supported by grants from The Swedish Cancer Society, project no. 1870B83-01XA

\section{References}

Bicknell, D.C. \& Gower, D.B. (1971) The separation of $C_{19}$-16-unsaturated steroids from $C_{21}$ and other $C_{19^{-}}$ steroids by two-dimensional thin-layer chromatography. J. Chromatogr. 61, 358-360.
Falck, B. (1959) Site of production of oestrogen in rat ovary as studied in micro-transplants. Acta physiol. scand. 47, Suppl. 163, 1-101.

Forsberg, J.-G. (1969) The development of atypical 
epithelium in the mouse uterine cervix and vaginal fornix after neonatal oestradiol treatment. Br.J. exp. Path. 50, 187-195.

Forsberg, J.-G. \& Kalland, T. (1981) Neonatal estrogen treatment and epithelial abnormalities in the cervicovaginal epithelium of adult mice. Cancer Res. 41, 721-734.

Goldman, A.S. (1974) Sexual programing of the rat fetus and neonate studied by selective biochemical testosterone-depriving agents. Adv. Biosci. 13, 17-40.

Goldman, A.S. \& Bongiovanni, A.M. (1967) Induced genital anomalies. Ann. N.Y. Acad. Sci. 142, 755-767.

Goomer, N., Saxena, R.N. \& Sheth, A.R. (1977) Effect of neonatal testosterone and oestradiol treatment on the development of the hypothalamo-hypophysial axis in the female rat. J. Reprod. Fert. 50, 239-243.

Gorski, R.A., Harlan, R.E. \& Christensen, L.W. (1977) Perinatal hormonal exposure and the development of neuroendocrine regulatory processes. J. Toxicol. Environm. Health 3, 97-121.

Haney, A.F., Newbold, R.R. \& McLachlan, J.A. (1984) Prenatal diethylstilbestrol exposure in the mouse: effects on ovarian histology and steroidogenesis in vitro. Biol. Reprod. 30, 471-478.

Kawashima, S. \& Mori, T. (1971) Behavior of ovaries subcutaneously transplanted to ovariectomized hosts from normal and neonatally estrogenized donors. Proc. Japan Acad. Sci. 47, 76-80.

Kimura, T., Basu, S.L. \& Nandi, S. (1967) Nature of induced persistent vaginal cornification in mice. I. Effect of neonatal treatment with various doses of steroids. $J$. exp. Zool. 165, 71-88.
McLachlan, J.A., Newbold, R.R., Shah, H.C., Hogan, M.D. \& Dixon, R.L. (1982) Reduced fertility in female mice exposed transplacentally to diethylstilbestrol (DES). Fert. Steril. 38, 364-371.

Mori, T. (1979) Age-related changes in ovarian responsiveness to gonadotropins in normal and neonatally estrogenized mice. $J$. exp. Zool. 207, 451458.

Nagasawa, H., Yanai, R., Kikuyama, S. \& Mori, J. (1973) Pituitary secretion of prolactin, luteinizing hormone and follicle-stimulating hormone in adult female rats treated neonatally with oestrogen. J. Endocr. 59, 599604.

Spona, J. (1982) Norethisterone does not inhibit rat testis $\Delta^{5}-3 \beta$-hydroxysteroid dehydrogenase. FEBS Letters $144,283-288$.

Spona, J. (1983) Differences in inhibition by various steroids of rat testis and Pseudomonas testosteronii $\Delta^{5}-3 \beta$-hydroxysteroid dehydrogenase. Endocr. Exp. 17, $107-118$.

Takasugi, N. \& Bern, H. A. (1964) Tissue changes in mice with persistent vaginal cornification induced by early postnatal treatment with estrogen. J. natn. Cancer Inst. 33, 855-865.

Takasugi, N., Bern, H.A. \& DeOme, K.B. (1962) Persistent vaginal cornification in mice. Science, N.Y. 38, 438-439.

Takasugi, N., Kimura, T. \& Mori, T. (1970) Irreversible changes in mousevaginal epithelium induced by early postnatal treatment with steroid hormone. In The Postnatal Development of Phenotypes, pp. 229-240. Eds S. Kazda \& H. Denenberg. Academia, Prague.

Received 27 June 1984 